\title{
Bacterial Genetics
}

National Cancer Institute

\section{Source}

National Cancer Institute. Bacterial Genetics. NCI Thesaurus. Code C17601.

Subdiscipline of genetics with a focus on bacteria. 